\title{
Synthesis, Characterization and Optimization of Reaction Parameters for Sodium Salt of Partially Carboxymethylated Okra Gum
}

\author{
SAVAN H. PATEL, YOGESG M. BAJ and NIRMAL K. PATEL*
}

Department of Industrial Chemistry, Institute of Science \& Technology for Advanced Studies \& Research, Affiliated to Sardar Patel University, Vallabh Vidyanagar, Anand - 388120, Gujarat, India

drnirmalpatel@yahoo.com

Received 31 August 2017 / Accepted 1 October 2017

\begin{abstract}
Okra is an associate of the mallow family which is related to cotton, hibiscus and hollyhock. It is a tall annual tropical herb cultivated for its edible green seed pod. Okra gum was extracted from the pods of hibiscus esculents using acetone as a solvent. The solution of okra gum in water has the highest viscosity among all the natural polysaccharide exposed till date. Etherification of extracted okra gum was carried out to produce carboxymethylation okra gum. Reaction parameters such as reaction temperature, reaction time, volume of sodium hydroxide and amount of monochloroacetic acid were optimized. Physical and chemical characteristics such as solubility, $\mathrm{pH}$, moisture content and viscosity were observed for carboxymethylation okra gum. Further extracted okra gum and carboxymethylation okra gum were characterized by Fourier transform infrared spectroscopy.
\end{abstract}

Keywords: Okra gum, Extraction, Carboxymethylation, Monochloroacetic acid, Degree of substitution

\section{Introduction}

Today okra is popular in India, Africa, Middle East, Greece, Turkey, Caribbean, South America and Southern United States. It is not a very common vegetable in most European countries, except in Greece and some parts of Turkey. The major okra producing states in India are Gujarat, Uttar Pradesh, Bihar, Orissa, West Bengal, Andhra Pradesh and Karnataka. In West Bengal, $0.6 \mathrm{mmt}$ of okra is produced from 58,400 ha with an average productivity of $11.4 \mathrm{mt} / \mathrm{ha}$.

Okra or ladies finger (Bhindi) is one of the important vegetables in India. It is grown throughout the tropical and sub-tropical regions and also in the warmer parts of the regions. The nutritional value of $100 \mathrm{~g}$ of edible okra is $1.9 \mathrm{~g}$ protein, $0.2 \mathrm{~g}$ fat, $6.4 \mathrm{~g}$ carbohydrate, $0.7 \mathrm{~g}$ minerals and $1.2 \mathrm{~g}$ fibers. Okra has a good potential as an external exchanger crop and accounts for $60 \%$ of the export of fresh vegetables. It is cultivated in 0.3 mha area with the production of $3.3 \mathrm{mmt}$ and productivity of $9.6 \mathrm{mt} / \mathrm{ha}^{3,4}$. 
Okra gum is a glactomannan and is derived from seeds of abelmoschus esculents. It has biodegradability and biocompatibility. Okra gum derived from the pods of hibiscus esculents (Figure 1) is one of the advantageous polysaccharides that are currently being studied in the pharmaceutical industry as a hydrophilic polymer in pharmaceutical dosage forms ${ }^{5}$. Okra plant is grown in all soil types and is among the most heat and drought -tolerant vegetables ${ }^{6}$.

It has been investigated as a binding agent for tablets and has also been shown to produce tablets with good hardness, friability and drug release profiles ${ }^{7}$. It has advantage over most commercial synthetic polymers as it is safe, chemically inert, non-irritant, biodegradable, biocompatible and eco-friendly. It is economical as it is widely harvested and does not require toxicology studies ${ }^{8,9}$. The okra gum is also used in transdermal drug delivery systems as synthetic cervical mucus and as a viscous supplementation agent in osteoarthritis treatment, tablet binding and disintegration agent-controlled drug delivery systems, slimming aids, nutritional foods etc. ${ }^{10}$. Biodegradability, biocompatibility and easy availability of Okra gum encourage most scientists to focus their work on it. Okra gum is an economical thickener and stabilizer ${ }^{11,12}$.

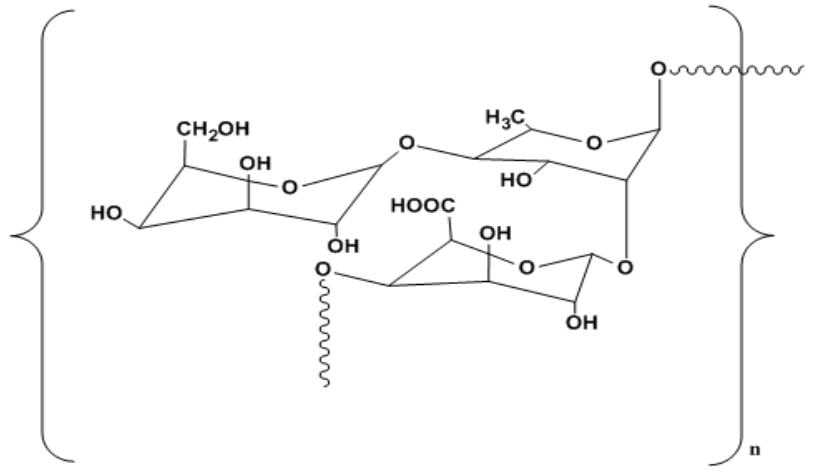

Figure 1. Chemical structure of polysaccharide of Okra mucilage

Okra gum is modified to improve its application in control release drug delivery system. The derivatives of okra gum are prepared by reaction like alkylation, esterification, etc. The derivatives of okra gum are prepared under different experimental conditions. Different properties such as moisture regain, rate of hydration, solubility, viscosity and rheology of the derivatives have been studied ${ }^{13,14}$. The properties depend upon polysaccharide chain length, the nature and degree of chemical modification. Chemical modification such as oxidation, acetylation, hydroxylpropylation and cross-linking provide efficient route not only to reduce the drawbacks but also to improve on the physicochemical properties and to introduce new properties for different applications ${ }^{15-17}$.

Okra gum or its derivatives are used in pharmaceutical industries as gelling, viscosifying, suspension, stabilization, emulsification, preservation, water retention/water phase control, binding, clouding/bodying, process aid, pour control for suspensions and anti-acid formulations. However, okra gum derivatives are used for controlling the release of drugs in the gastrointestinal tract such as, carrier for colon targeted drugs for anticancer drugs and for oral rehydration solutions in the treatment of cholera in adults. Also, it has many applications in various industries such as paper, food, textile, cosmetic, nutrition and animal feed ${ }^{18-20}$.

In the present work, okra gum was extracted from okra pod. The extracted okra gum was characterized by moisture content, $\mathrm{pH}$, solubility test, viscosity, DS. Carboxymethylation of extracted okra gum was carried out. Effect of different parameters viz. time, temperature, effect of $\mathrm{NaOH}$ and effect of monochloroacetic acid on carboxymethylation was studied. 


\section{Experimental}

Okra fruit was purchased from local vegetable market. Sodium hydroxide, monochloroacetic acid, methanol and isopropyl alcohol were purchased from Atul Chemical, Anand. Solvents and other laboratory chemicals were used after routine purification and they were of analytical reagent grade. Double distilled water was used.

\section{Methods}

\section{Extraction of okra gum}

$500 \mathrm{~g}$ of unripe and tender okra fruit was washed and sliced with a knife. The sliced mass was soaked in distilled water overnight. After soaking, white muslin cloth was used to filter out the viscous gum extract. Acetone was added to precipitate the gum at a ratio of $1 / 3$ parts of acetone to 1 part of the gum extract. The precipitated gum was dried in a desiccator containing anhydrous calcium chloride for approximately 15 days. Size reduction and screening of the dried gum were carried out using a stainless steel grinder and no. 30 stainless steel mesh sieve. Airtight powder bottles were used to store the undersize fractions.

\section{Purification of okra gum}

$2 \mathrm{~g}$ of the okra gum was boiled with $8 \mathrm{~mL}$ of $70 \%$ (v/v) ethanol for $1 \mathrm{~h}$ with reflux. The sample was filtered, washing with $95 \%$ (v/v) ethanol and dried at $60{ }^{\circ} \mathrm{C}$ for $3 \mathrm{~h}$ in vacuum oven.

\section{Carboxymethylation of okra gum}

Carboxymethylation of okra gum was carried out by mixing extracted okra gum with 4 $\mathrm{mL}$ of distilled water which was heated to $80{ }^{\circ} \mathrm{C}$ for $15 \mathrm{~min}$. After that, $56 \% \mathrm{w} / \mathrm{v}$ of icecold sodium hydroxide solution was added drop by drop over a period of $45 \mathrm{~min}$. Monochloro-acetic acid solution was added slowly for a period of $60 \mathrm{~min}$. to the above mixture and maintained the temperature at $15{ }^{\circ} \mathrm{C}$. The temperature of the mixture was raised slowly to $65{ }^{\circ} \mathrm{C}$ and stirred for another $6 \mathrm{~h}$. The wetted mass was washed with methanol for $30 \mathrm{~min}$. The $\mathrm{pH}$ of the suspension was adjusted to neutrality with glacial acetic acid, and then it was dried at $50-60{ }^{\circ} \mathrm{C}$.

\section{Purification of carboxymethyl okra gum}

Carboxymethyl okra gum was purified with water. Product remained dialyzed as compared to distilled water for $48 \mathrm{~h}$ and then carboxymethyl okra gum was precipitated with methanol. Finally product was dried in oven at temperature of $40-45^{\circ} \mathrm{C}$.

\section{Characterization of extracted okra gum}

\section{Moisture content}

The moisture content of the sample is calculated using the following equation:

$$
\% W=\frac{A-B}{A} x 100
$$

Where, $\% \mathrm{~W}=$ Percentage of moisture in the sample, $\mathrm{A}=$ Weight of wet sample $(\mathrm{g})$, $\mathrm{B}=$ Weight of dry sample $(\mathrm{g})$

\section{pH Determination}

$1 \% \mathrm{w} / \mathrm{v}$ dispersion of the sample in water was stirred consistently for $5 \mathrm{~min}$. and $\mathrm{pH}$ was determined using a pH meter with built in magnetic stirrer model Equiptronics-614. 


\section{Solubility test}

Solubility of the extracted okra gum was evaluated qualitatively by stirring $10 \mathrm{mg}$ of okra powder in $10 \mathrm{~mL}$ water, acetone, chloroform, dimethyl sulfoxide (DMSO), dimethyl formamide (DMF) and methanol. Solubility was determined by visual observation of the solute.

\section{Viscosity}

Viscosity of okra gum at $1 \%$ and $0.5 \%$ concentrations was measured using the Gardner bubble viscometer.

\section{Characterization of extracted carboxymethylation okra gum}

The moisture content of the sample was calculated using Eq. 1. The pH determination, solubility test and viscosity measurments were carryout as per the procedure explained in the previous section.

\section{Degree of substitution in carboxymethylation okra gum}

$1 \mathrm{~g}$ of Na-carboxymethyl okra gum was dissolved in required amount of water. Then this solution was passed through regenerated Amberlite anion exchange resin several times till it became acidic. As a result, solution was divided into two equal parts labeled as solution 1 and solution 2 . The exhausted resin was regenerated by passing $1 \mathrm{~N} \mathrm{HCl}$ solution (3-4 times) followed by washing with distilled water to remove any excess acid.

Solution 1 was taken into previously weighed beaker. The solution was heated until all solvents on hot plate evaporated. Then the solution was cooled and Na- Carboxymethyl okra gum was weighed.

Solution 2 was titrated against a standard solution of $\mathrm{NaOH}$. The burette reading was noted down and the degree of substitution was found out by following equation (2).

$$
\begin{aligned}
& \text { Degree of substitution }=0.162 \mathrm{~B} /(1-0.58 \mathrm{~B}) \\
& \text { Where, } \mathrm{B}=\text { Volume of } \mathrm{NaOH} / \text { Weight of sample }
\end{aligned}
$$

\section{Results and Discussion}

\section{Optimization study of parameters}

Carboxymethylation reaction was carried out at variable amount of $\mathrm{NaOH}$ from 2-12 mL (Table 1). But degree of substitution (DS) increased as a result of increasing the amount of $\mathrm{NaOH}$ up to $10 \mathrm{~mL}$. There was no change in the degree of substitution when $\mathrm{NaOH}$ was used in the amounts of $10 \mathrm{~mL}$ and $12 \mathrm{~mL}$. So we found $10 \mathrm{~mL} \mathrm{NaOH}$ is the best proportion. Increase in amount of $\mathrm{NaOH}$ leads to the alkali degradation of polymer. The lower amount of $\mathrm{NaOH}$ leads to lower number of free hydroxyl group deprotonated to form alkoxide which was resulted into lower value of degree of substitution.

Table 1. Effect of $\mathrm{NaOH}$

\begin{tabular}{cccccc}
\hline S. No. & $\begin{array}{c}\mathrm{NaOH}, \\
\mathrm{mL}, 30 \%\end{array}$ & $\begin{array}{c}\text { Temperature, } \\
{ }^{\circ} \mathrm{C}\end{array}$ & $\begin{array}{c}\text { Monochloro- } \\
\text { acetic acid, } \mathrm{g}\end{array}$ & $\begin{array}{c}\text { Time, } \\
\mathrm{h}\end{array}$ & $\begin{array}{c}\text { Degree of } \\
\text { substitution }\end{array}$ \\
\hline 1 & 2 & 60 & 10 & 6 & 0.35 \\
2 & 4 & 60 & 10 & 6 & 0.36 \\
3 & 6 & 60 & 10 & 6 & 0.39 \\
4 & 8 & 60 & 10 & 6 & 0.55 \\
5 & 10 & 60 & 10 & 6 & 1.11 \\
6 & 12 & 60 & 10 & 6 & 0.99 \\
\hline
\end{tabular}


Table 2. Effect of monochloroacetic acid

\begin{tabular}{cccccc}
\hline S. No. & $\begin{array}{c}\text { Monochloro- } \\
\text { acetic acid, }\end{array}$ & $\begin{array}{c}\mathrm{NaOH}, \\
\mathrm{mL}, 30 \%\end{array}$ & $\begin{array}{c}\text { Temperature, } \\
{ }^{\circ} \mathrm{C}\end{array}$ & $\begin{array}{c}\text { Time, } \\
\mathrm{h}\end{array}$ & $\begin{array}{c}\text { Degree of } \\
\text { substitution }\end{array}$ \\
\hline 1 & 2 & 10 & 60 & 6 & 0.34 \\
2 & 4 & 10 & 60 & 6 & 0.36 \\
3 & 6 & 10 & 60 & 6 & 0.40 \\
4 & 8 & 10 & 60 & 6 & 0.60 \\
5 & 10 & 10 & 60 & 6 & 1.11 \\
6 & 12 & 10 & 60 & 6 & 1.11 \\
\hline
\end{tabular}

Carboxymethylation reaction was carried out by varying amount of monochloroacetic acid from 2-12 g (Table 2). But degree of substitution increase as a result of increasing the amount of monochloroacetic acid up to $10 \mathrm{~g}$. The reaction remains constant by further increase in the amount of monochloroacetic acid there was no change in the degree of substitution with increase in monochloroacetic acid, So we found $10 \mathrm{~g}$ monochloroacetic acid is the best proportion. If the less amount of monochloroacetic acid used then it leads to unneutralization of alkali so the optimum monochloroacetic aid (10 g) was used to leads the favorable neutralization of alkali and to better formation of carboxymethylation okra gum having higher degree of substitution value.

Carboxymethylation reaction was carried out in the duration of 3-7 h, keeping other limits constant (Table 3). It can be settled from the table that degree of substitution improved with increase in time from 3-6 h. But degree of substitution was almost same at the end of $6 \mathrm{~h}$ and $7 \mathrm{~h}$. So we selected $6 \mathrm{~h}$ is the best reaction time. Besides, carrying out the reaction for $7 \mathrm{~h}$ (i.e. one hour more) was likely to increase the production cost.

Table 3. Effect of time

\begin{tabular}{cccccc}
\hline S. No. & $\begin{array}{c}\text { Time, } \\
\mathrm{h}\end{array}$ & $\begin{array}{c}\mathrm{NaOH}, \\
\mathrm{mL}, 30 \%\end{array}$ & $\begin{array}{c}\text { Monochloro- } \\
\text { acetic acid, }\end{array}$ & Temperature, ${ }^{\circ} \mathrm{C}$ & $\begin{array}{c}\text { Degree of } \\
\text { substitution }\end{array}$ \\
\hline 1 & 3 & 10 & 10 & 60 & 0.36 \\
2 & 4 & 10 & 10 & 60 & 0.40 \\
3 & 5 & 10 & 10 & 60 & 0.56 \\
4 & 6 & 10 & 10 & 60 & 1.11 \\
5 & 7 & 10 & 10 & 60 & 1.12 \\
\hline
\end{tabular}

Carboxymethylation reaction was carried out in the range of $30-70{ }^{\circ} \mathrm{C}$, keeping other limits constant (Table 4). It can be perceived from the table that degree of substitution improved with increase in temperature from $30-60{ }^{\circ} \mathrm{C}$. But the degree of substitution obtained at $70{ }^{0} \mathrm{C}$ was almost same as obtained at $60{ }^{\circ} \mathrm{C}$. Beside maintaining temperature higher than $60^{\circ} \mathrm{C}$ was likely to increase the production cost. So we selected $60{ }^{\circ} \mathrm{C}$ as the best reaction temperature.

Table 4. Effect of temperature

\begin{tabular}{cccccc}
\hline S. No & $\begin{array}{c}\text { Temperature, } \\
{ }^{\circ} \mathrm{C}\end{array}$ & $\begin{array}{c}\text { NaOH, } \\
\mathrm{mL}, 30 \%\end{array}$ & $\begin{array}{c}\text { Monochloro- } \\
\text { acetic acid, }\end{array}$ & $\begin{array}{c}\text { Time, } \\
\mathrm{h}\end{array}$ & $\begin{array}{c}\text { Degree of } \\
\text { substitution }\end{array}$ \\
\hline 1 & 30 & 10 & 10 & 6 & 0.37 \\
2 & 40 & 10 & 10 & 6 & 0.42 \\
3 & 50 & 10 & 10 & 6 & 0.60 \\
4 & 60 & 10 & 10 & 6 & 1.11 \\
5 & 70 & 10 & 10 & 6 & 1.13 \\
\hline
\end{tabular}


Table 5. Characterization study of okra gum

\begin{tabular}{lcc}
\hline Properties & Extracted okra gum & Carboxymethylated okra gum \\
\hline Moisture content & $10.96 \%$ & $9.4 \%$ \\
$\mathrm{pH}^{*}$ & 6.59 & 9.10 \\
Solubility & Soluble in water & soluble in water \\
& Insoluble in acetone, & Insoluble in acetone, \\
& chloroform, methanol, & chloroform, methanol, \\
Viscosity $^{* *}$ & DMSO and DMF. & DMSO and DMF. \\
& 53.6 cSt (A tube) & $31 \mathrm{cSt}$ (A tube) \\
& and 68.8 cSt (B tube) & $21.3 \mathrm{cSt}$ (B tube) \\
\hline
\end{tabular}

${ }^{*}$ For $1 \% \mathrm{w} / \mathrm{v}$ solution, ${ }^{* *} 1 \%$ aqueous solution used in tube $\mathrm{A} \& 0.5 \%$ in tube B (Gardner-bubble viscometer method)

\section{Characterization study}

Characterization study for the extracted okra gum and extracted carboxymethylated okra gum was carried out and the values are listed in the Table 5.

FTIR spectrums of okra gum were shown in Figure 2. The absorption band at $3471.23 \mathrm{~cm}^{-1}$ in IR spectrum of okra gum showed intensity for the hydroxyl group present in okra gum. The sharp absorption band located at $2927.47 \mathrm{~cm}^{-1}$ may be attributed to $\mathrm{CH}$ group stretching.

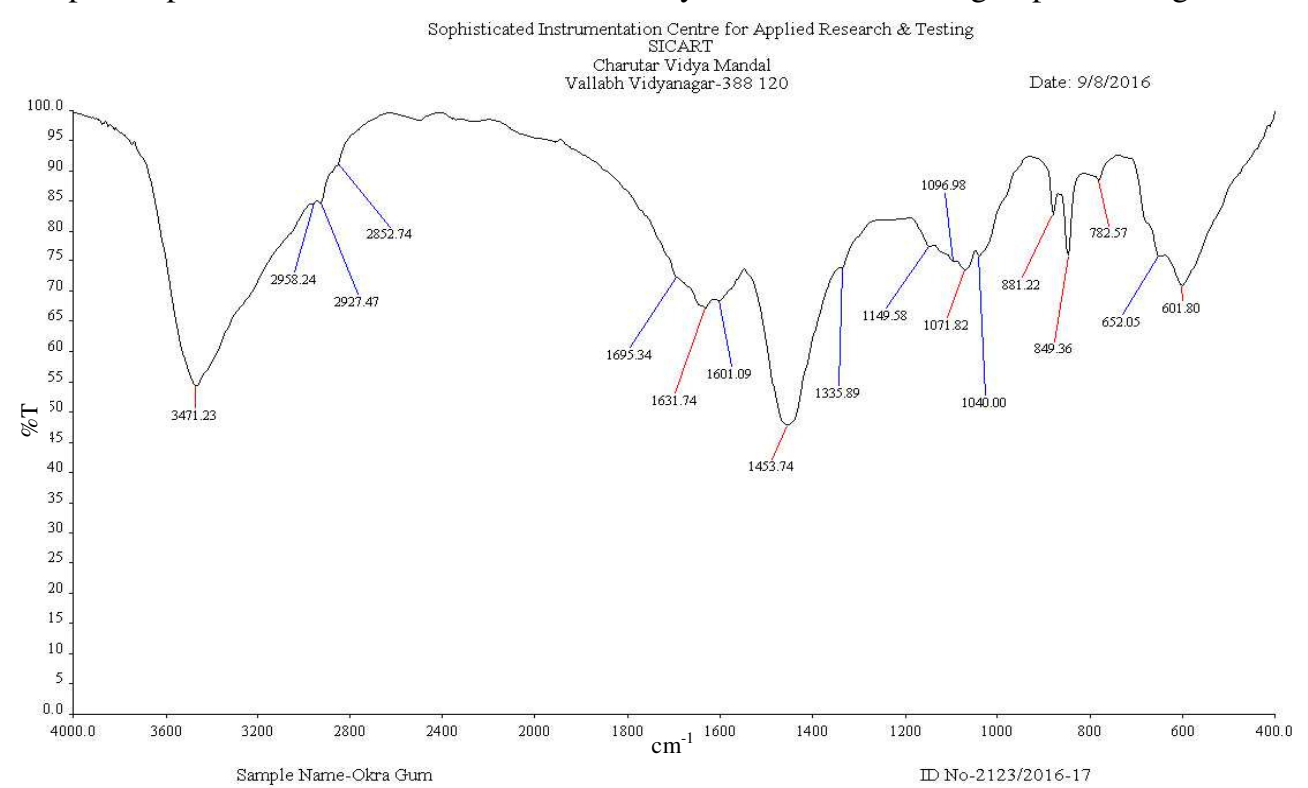

Figure 2. FTIR Spectroscopy of okra gum

FTIR spectrum of carboxymethylated okra gum is shown in Figure 3. The IR spectrum of carboxymethylated okra gum showed a reduced intensity of the absorption band located at $3436.51 \mathrm{~cm}^{-1}$, as compared to okra gum IR spectrum. This happened due to -OH stretching which indicated that some - $\mathrm{OH}$ group were carboxymethylated. The sharp absorption band located at $2926.26 \mathrm{~cm}^{-1}$ may be attributed to $\mathrm{CH}$ group stretching. The $\mathrm{C}-\mathrm{O}$ symmetrical and asymmetrical vibrations at a frequency of $1072.27 \mathrm{~cm}^{-1}$ confirms the incorporation of the carboxymethyl group to the okra gum molecule, which is absent in the okra gum spectra. 


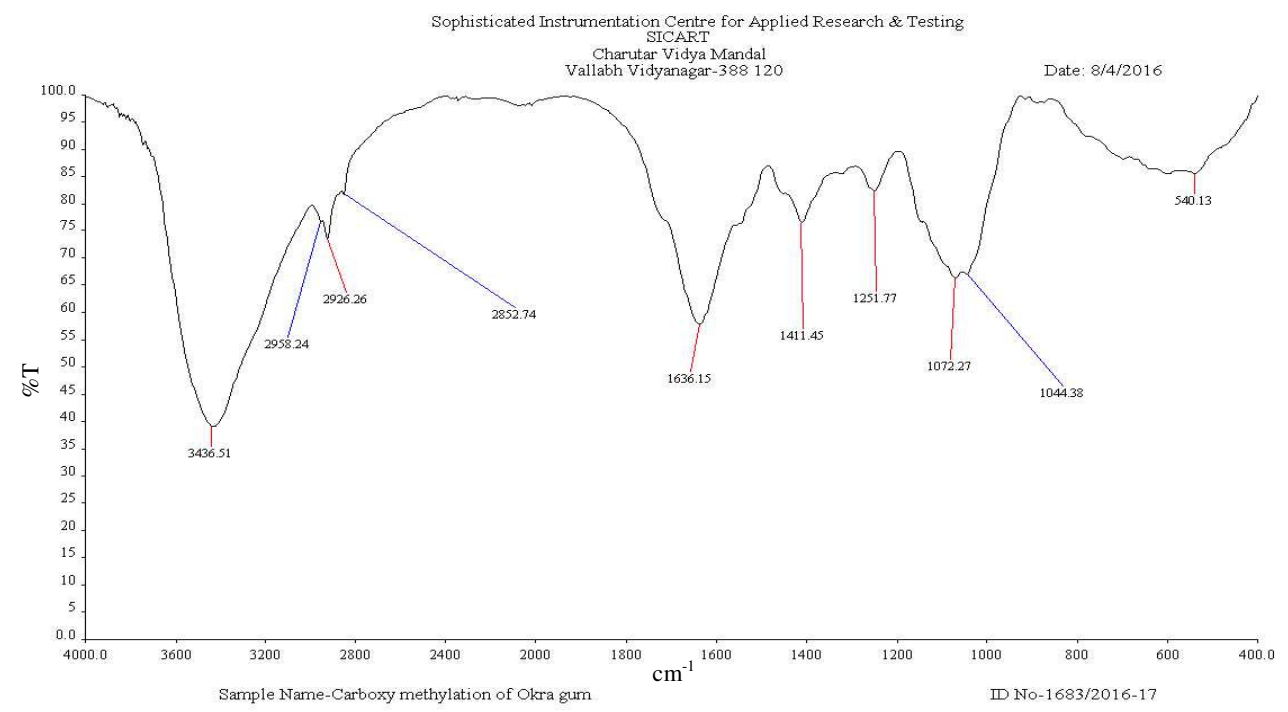

Figure 3. FTIR Spectroscopy of carboxymethylated of okra gum

\section{Conclusion}

The carboxymethylation of okra gum was carried out successfully and it is confirmed by FTIR. Carboxymethylation increases the properties of okra gum, moisture content and viscosity. The optimization study for carboxymethylation of okra gum was carried out. The optimum degree of substitution of 1.11 was obtained by carrying out reaction at $60{ }^{\circ} \mathrm{C}$ for $6 \mathrm{~h}$ by addition $10 \mathrm{~mL}(30 \%)$ of $\mathrm{NaOH}$ and $10 \mathrm{~g}$ of monochloroacetic acid.

\section{References}

1. Chodavarapu N P, Yendluri R B, Suryadevara H, Reddy P and Chhatoi P, J Pharm Technol., 2011, 6(8), 16-20.

2. Kumar S, Dagnoko S, Haougui A, Ratnadass A, Pasternak D and Kouame C, J Agr Res., 2010, 5(25), 3590-3598; DOI:10.5897/AJAR10.839

3. Anwar F, Rashid U, Ashraf M and Nadeem M, Appl Energy, 2010, 87(3), 779-785; DOI:10.1016/j.apenergy.2009.09.020

4. Kulkarni G T, Gowthamarajan K, Dhobe R R, Yohanan F and Suresh B, Drug Delivery, 2005, 12(4), 201-206; DOI:10.1080/10717540590952537

5. Avulapati S, Roy A K, Shashidhar K R and Ugendarreddy T, Int J Drug Develop Res., 2011, 3(1), 45-51.

6. Ilango K, Mishra M, Devi S, Rajsekaran A, Senthil Kumar M and Subburaju T, $J$ Pharm Sci Rev Res., 2010, 5(1), 138-145.

7. Jani G K, Shah D P, Prajapati V D and Jain V C, Asian J Pharm Sci., 2009, 4(5), 309-323.

8. Gemede H F, Haki G D, Beyene F, Woldegiorgis A Z and Rakshit S K, Food Sci Nutri., 2015, 4(2), 223-233; DOI:10.1002/fsn3.282

9. Shaikh T and Kumar S S, J Pharmacy Pharm Sci., 2011, 3(5), 38-40.

10. Kaur L, Bala R, Kanojia N, Nagpal M and Dhingra G A, Int Scholarly Res Notices, 2014, Article id 242504; DOI:10.1155/2014/242504

11. Kumar R, Patil S, Patil M B, Patil S R and Paschapur M S, J PharmTech Res., 2009, 1(4), 982-996. 
12. Balasubramaniam J, Bindu K, Rao V U, Ray D, Haldar R and Brzeczko A W, Dissolution Technologies, 2008, 15(2), 18-25; DOI:10.14227/DT150208P18

13. Patel J J, Karve M and Patel N K, Int J Pharm Pharm Sci., 2014, 6(8), 13-19.

14. Shukla D, Chakraborty S, Singh S and Mishra B, Scientia Pharmaceutica, 2009, 77(2), 309-326.

15. Mukherjee I and Rosolen M, J Thermal Anal Calorimetry, 2013, 114(3), 1161-1166; DOI:10.1007/s10973-013-3166-4

16. Morillon V, Debeaufort F, Capelle M, Blond G, and Voilley A, J Agr Food Chem., 2000, 48(1), 11-16; DOI:10.1021/jf990809z

17. Tavakoli N, Teimouri R and Hamishehkar H, J Natural Pharm Prod., 2007, 3(1), 33-38.

18. Kalu V D, Odeniyi M A and Jaiyeoba K T, Arch Pharm Res., 2007, 30(7), 884-889; DOI:10.1007/BF02978841

19. Pittler M H and Ernst E, The J Am Med., 2001, 110(9), 724-730; DOI:10.1016/S00029343(01)00702-1

20. Robinson G, Ross-Murphy S B and Morris E R, Carbohydrate Res., 1982, 107(1), 17-32; DOI:10.1016/S0008-6215(00)80772-7 